\title{
Isolation, Assay, and Secretion of Individual Human Neurophysins
}

\author{
Alan G. Robinson \\ From the Division of Endocrinology and Metabolism, Department of Medicine, \\ University of Pittsburgh School of Medicine, Pittsburgh, Pennsylvania 15261
}

\begin{abstract}
A B S T R A C T Human neurophysin was isolated from acetone-dried human posterior pituitaries and separated into two major neurophysin peptides by ion exchange chromatography and into four major peptides by preparative disk gel electrophoresis. Antisera raised in rabbits distinguished only two specific antigenic sites on the isolated neurophysin peptides. Individual sensitive and specific radioimmunoassays for two human neurophysins were developed. These assays were used to measure each neurophysin in unextracted human plasma. The two neurophysins are secreted independently in man. One assay measures a neurophysin that is specifically secreted in response to estrogen administration, estrogen-stimulated neurophysin (ESN). The other assay measures a neurophysin that is specifically secreted in response to cigarette smoking, nicotinestimulated neurophysin (NSN). The mean ESN is $1.1 \mathrm{ng} / \mathrm{ml} \pm 0.7 \mathrm{SD}$ in women and $1.0 \mathrm{ng} / \mathrm{ml} \pm 0.7 \mathrm{SD}$ in men. The mean NSN is $0.9 \mathrm{ng} / \mathrm{ml} \pm 0.2 \mathrm{SD}$ in women and $0.6 \mathrm{ng} / \mathrm{ml} \pm 0.3 \mathrm{SD}$ in men. It is proposed that these may prove to be a specific human "oxytocinneurophysin," ESN, and a human "vasopressin-neurophysin," NSN.
\end{abstract}

\section{INTRODUCTION}

It is now established that the intraneuronal neurophysins, which are synthesized and stored with vasopressin and oxytocin in the neurohypophysis, are secreted into the bloodstream (1-10). Many species have two or more neurophysins in their pituitary $(3,6,11$, 12), and data in the cow have suggested that there might be a specific neurophysin secreted with oxytocin and a different neurophysin secreted with vasopressin (7). Data in studies of the rat and pig support the concept of a specific oxytocin neurophysin

Received for publication 12 June 1974 and in revised form 11 October 1974. and a vasopressin neurophysin $(12,13)$, but independent assays of different neurophysins in these species have not been accomplished. In the present report, neurophysins have been isolated from human posterior pituitaries, and two neurophysins have been identified by their immunologic specificity. Radioimmunoassays for these two neurophysins have been developed, and independent secretion of each has been demonstrated in normal humans.

\section{METHODS}

The starting material was 2,000 intact acetone-preserved whole human pituitaries. Posterior pituitaries were separated from these glands by blunt dissection and air-dried. The glands were extracted by the method of Hollenberg and Hope (14). $10 \mathrm{~g}$ of dried posterior pituitaries were crushed in $0.1 \mathrm{~N} \mathrm{HCl}$ using a mortar and pestle and extracted overnight at $4^{\circ} \mathrm{C}$ in $400 \mathrm{ml} 0.1 \mathrm{~N} \mathrm{HCl}$ (final pH 1.5). The suspension was centrifuged at $2,200 \mathrm{~g}$ for $1 \mathrm{~h}$, and the sediment was re-extracted overnight at $4^{\circ} \mathrm{C}$ in an additional $400 \mathrm{ml}$ of $0.1 \mathrm{~N} \mathrm{HCl}$. The following day the suspension was again centrifuged, and the supernatant fluids were combined. The amber-colored liquid was titrated to $\mathrm{pH} 7$ with concentrated $\mathrm{NaOH}$ (at $4^{\circ} \mathrm{C}$ ). A white precipitate formed which was removed by centrifugation at 31,000 $g$ for $30 \mathrm{~min}$ at $4^{\circ} \mathrm{C}$. The $\mathrm{pH}$ of the supernate was adjusted to 3.9 with $10 \mathrm{~N} \mathrm{HCl}$, and $80 \mathrm{~g}$ of $\mathrm{NaCl}$ was added to the extract which was constantly stirred at $4^{\circ} \mathrm{C}$ for $24 \mathrm{~h}$. A precipitate formed which was isolated by centrifugation at $31,000 \mathrm{~g}$ for $30 \mathrm{~min}$ at $4^{\circ} \mathrm{C}$. This has been referred to as neurophysin-hormone complex (14). The precipitate was dialyzed against multiple changes of distilled water at $4^{\circ} \mathrm{C}$ over 2 days and then lyophilized. The yield of the extraction steps per gram of pituitaries is shown in Table I. The crude neurophysin-hormone complex $(70 \mathrm{mg})$ was dissolved in $3.5 \mathrm{ml}$ of $0.1 \mathrm{~N}$ formic acid and applied to a Sephadex G-75 column, $2.5 \times 100 \mathrm{~cm}$. The typical elution pattern in $0.1 \mathrm{~N}$ formic acid was four peaks (Fig. 1) with 25-30\% of the added protein in the third peak, the neurophysin peak. The neurophysin peak was identified by adding a trace of "1-labeled "human neurophysin I" obtained from Cheng and Friesen. Approximately $10 \%$ of the protein initially extracted in $0.1 \mathrm{~N} \mathrm{HCl}$ was finally isolated as crude neurophysin (Table I).

This peak was further proven to be neurophysin by its 
TABLE I

Yield of the Extraction Steps Per Gram of Pituitaries

$1,000 \mathrm{mg}$ posterior pituitary powder

extracted in $40 \mathrm{ml} 0.1 \mathrm{~N} \mathrm{HCl}$

$114 \mathrm{mg}$ protein

$$
\mid \begin{aligned}
& \mathrm{pH} \text { adjusted to } 7.0 \text { with } \mathrm{NaOH} \\
& \rightarrow 27 \mathrm{mg} \text { protein precipitate }
\end{aligned}
$$

$\mathrm{pH}$ adjusted to 3.9 with $\mathrm{HCl}$

$10 \mathrm{~g} \mathrm{NaCl} / 100 \mathrm{ml}$

$40 \mathrm{mg}$ protein, neutrophysin-hormone complex

Sephadex G-75 chromatography in $0.1 \mathrm{~N}$ formic acid

$10 \mathrm{mg}$ protein, crude neurophysin

ability to bind an oxytocin analogue at $\mathrm{pH}$ 5.8. Binding was tested on a Sephadex G-25 column $(1 \times 20 \mathrm{~cm})$ in sodium acetate buffer, $0.25 \mathrm{M}$ pH 5.8 with $0.01 \mathrm{M} \mathrm{Na}$ EDTA. When run alone, the crude neurophysin is eluted in the void volume, $6-8 \mathrm{ml}$, and $\left(4-\left[{ }^{14} \mathrm{C}\right]\right.$ glycine)-oxytocin run alone is eluted as a single peak at $11-16 \mathrm{ml}$. Crude bovine neurophysin, $1 \mathrm{mg}$, that has been described previously (6), was incubated overnight at $4^{\circ} \mathrm{C}$ with $10,000 \mathrm{cpm}$ of the oxytocin analogue (approximately $5 \mathrm{pg}$ ) in a volume of $150 \mu 1$ to determine binding of the analogue with a known neurophysin. After incubation, the mixture was run on the Sephadex G-25 column, and $60 \%$ of the counts were eluted in the void volume with the neurophysin. The crude human neurophysin bound $70 \%$ of the analogue under the same conditions. In contrast, the other major protein eluted from Sephadex G-75 (Fig. 1, first peak) was incubated with '1e oxytocin analogue, and no radioactivity was found in the protein peak when this was eluted from Sephadex G-25.

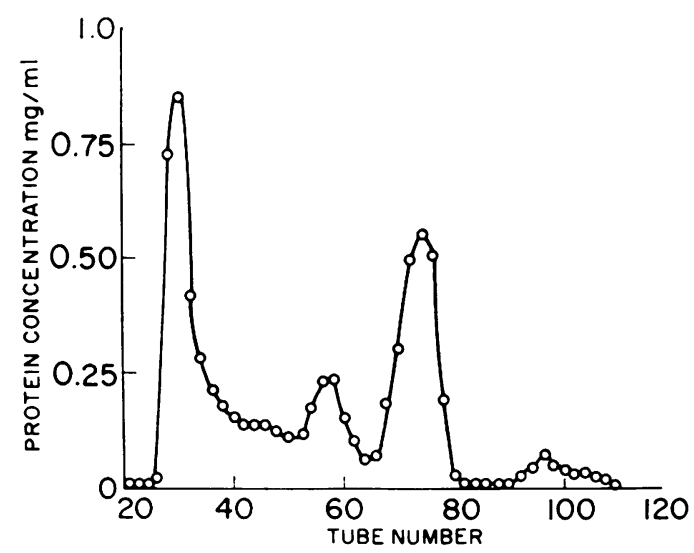

FIGURE 1 Chromatography of neurophysin-hormone complex on Sephadex G-75 column in $0.1 \mathrm{~N}$ formic acid. The neurophysin peak is tubes $66-80$. Fraction tube volume was $5 \mathrm{ml}$.

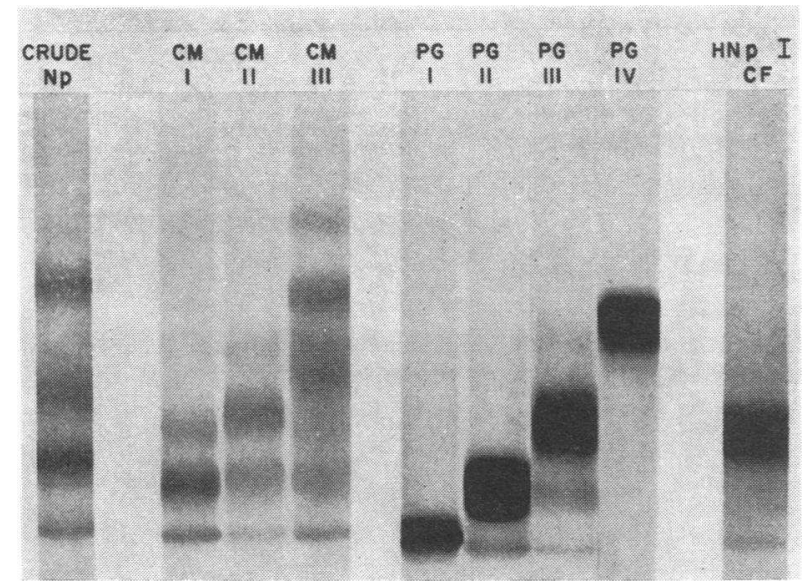

FIGURE 2 Analytic disk gel electrophoresis of various neurophysins. Crude $\mathrm{Np}$ (far left) is the neurophysin peak off Sephadex G-75. CM 1-3 are the three peaks off carboxymethyl Sephadex CM-50 when crude neurophysin is applied. PG I-IV are the four neurophysins isolated from crude neurophysin by preparative disk gel electrophoresis. $\mathrm{HNp}$ $\mathrm{I}-\mathrm{CF}$ is human neurophysin from Cheng and Friesen.

The crude neurophysin when examined by analytic disk gel (6) gave four bands as shown in Fig. 2.

During early extraction studies Sephadex CM-50 was utilized to separate individual neurophysins on a $1 \times 50-\mathrm{cm}$ column. The crude neurophysin from the G-75 column was concentrated by lyophilization. $75 \mathrm{mg}$ of this neurophysin

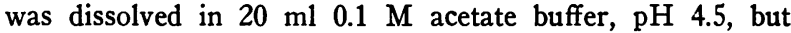
when this solution was added to the CM 50 column, a white precipitate was visible on the top of the column. The precipitate slowly dissolved as $800 \mathrm{ml}$ of $0.1 \mathrm{M}$ sodium acetate buffer, $\mathrm{pH} 4.5$, was followed by $600 \mathrm{ml}$ of $0.1 \mathrm{M}$ sodium acetate buffer, $\mathrm{pH} 5.0$, and no precipitate was visible at the end of the run. The three peaks that were eluted (Fig. 3) were individually pooled and concentrated by ultrafiltration. The first peak, CM I, contained $13.5 \mathrm{mg}$ protein, the second peak, CM II, $6.5 \mathrm{mg}$, and the third peak, CM

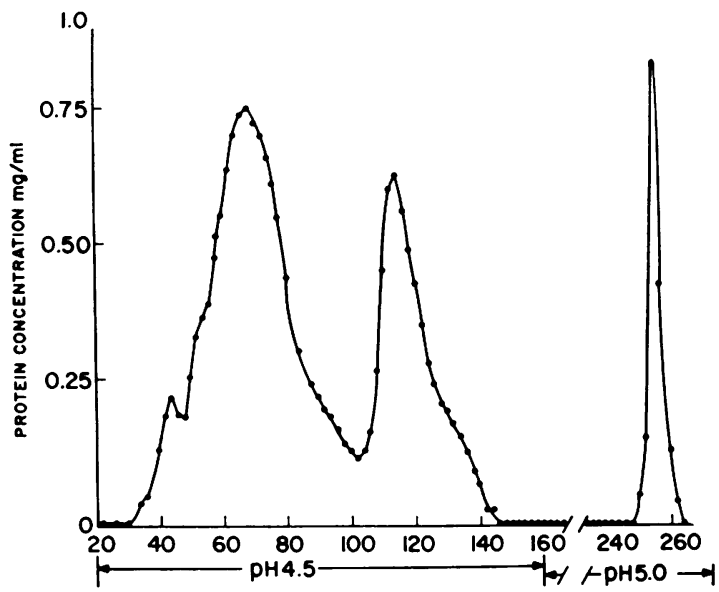

FIGURE 3 Chromatography of crude neurophysin on carboxy-methyl Sephadex CM-50 in 0.1 M sodium acetate buffer. Fraction tube volume was $5 \mathrm{ml}$. 
III, $5 \mathrm{mg}$. The total yield, $25 \mathrm{mg}$, was $33 \%$ of the crude neurophysin applied. These protein peaks gave analytic disk gel patterns as shown in Fig. 2. A predominant band was present in CM I, and a later migrating band was prominent in CM II. Both of these peaks had other bands, however, and several bands were present in CM III. CM I and CM II were the proteins used for rabbit immunization. Because CM III had numerous bands on disk gel, it was considered unsuitable for immunization and was not further investigated.

Because of the low yield on Sephadex CM-50, the incomplete separation, and the possible significance of the several bands in CM III, subsequent separations of crude neurophysin were undertaken with preparative disk gel electrophoresis. This was performed in a Shandon apparatus (Shandon Southern Instruments Inc., Sewickley, Pa.) using an $8-\mathrm{cm}$ separating gel of $7.5 \%$ acrylamide and a 1 $\mathrm{cm}$ stacking gel of $3 \%$ acrylamide, both in Tris-glycine buffer ( $\mathrm{pH} 8.5$ ) with $6 \mathrm{M}$ urea. The porous plastic gel contact ring furnished with this apparatus was not necessary to keep the gel in the column and was omitted from the bottom of the column. An ultrafiltration membrane (Diaflo PM-10, 75-mm diameter, Diaflo Ultrafiltration Membranes, Amicon Corp., Lexington, Mass.) was used to allow exact definition of the floor of the elution chamber. The elution chamber was flushed constantly with Tris-acetate elution buffer at $180 \mathrm{ml} / \mathrm{h}$ by a peristaltic pump. The column was run at room temperature. Volumes of $1 \mathrm{ml}$ effluent were collected in a fraction collector. After every 10th tube, the chamber was flushed with $5 \mathrm{ml}$ of elution buffer. A threeway stopclock was permanently placed in the inlet tubing of the elution chamber for flushing. Crude neurophysin (25-75 mg) was applied to the gel in a solution of Trisglycine buffer $\mathrm{pH} 8.5$ containing $10 \%$ sucrose. Three drops of $0.005 \%$ bromphenol blue were added to the sample, and periodic flushing of the elution chamber was begun when this tracking dye was first seen in the effluent. An entire run was completed in 6-8 h.

Protein determinations of the eluant fractions was attempted by the folin method of Lowry, Rosebrough, Farr, and Randall (15), and by UV $280 \mathrm{~nm}$. Both were unreliable to locate protein in the effluent because interfering substances were eluted from the gel. All tubes gave a positive reaction. Analytic disk gel electrophoresis using $10 \mu \mathrm{l}$ of effluent from alternate tubes was done to identify the various protein bands. Fractions were combined according to their protein bands on the analytical disk gel. Urea and ferritin (see below) used in the preparative gels were omitted from the analytic gels, and the separation was run in $7 \times 85-\mathrm{mm}$ tubes. Four distinct bands of neurophysin were obtained by preparative disk gel electrophoresis as shown in Fig. 2. Relatively pure peaks of bands PG I, PG II, PG III, and PG IV were individually pooled. The intervening tubes were pooled separately. The material that eluted from the gel and that gave a positive reaction with the test of Lowry, et al. (15), but did not show a positive band by analytic disk gel, was determined to have a low molecular weight. Rechromatographing the neurophysins that had been isolated by preparative disk gel on Sephadex G-75, $1.5 \times 100$ $\mathrm{cm}$, in $0.1 \mathrm{~N}$ formic acid, yielded a typical neurophysin peak that was distinctly separated from the nonprotein Lowry-positive material that emerged near, but not with, the salt peak. After repurification by Sephadex G-75 chromatography, the overall yield of the preparative disk gel electrophoresis was approximately $33 \%$, not different from that obtained with Sephadex CM-50 chromatography but with the isolation of extra bands. In consultation with $\mathrm{Dr}$.
Andreas Chrambach (16), it was suggested that $0.5 \mathrm{mg} / \mathrm{ml}$ horse ferritin be added to the gel in the gelling step. Preparative disk gel electrophoresis with this ferritin (Schwarz-Mann lot no. 3714, Schwarz/Mann Div., Becton, Dickinson and Co., Orangeburg, N. Y.) -coated column yielded neurophysin bands qualitatively similar to the previous run. A small amount of ferritin contaminated the neurophysins, but the Sephadex G-75 chromatography that was done to remove the Lowry-positive material also removed the ferritin. The high molecular weight ferritin was eluted as a small peak in the void volume. The overall recovery of neurophysin with this modification was $60-75 \%$ of the applied protein.

The individual protein peaks from the CM 50 column and the preparative disk gel electrophoresis were identified as neurophysin by their binding by antiserum to bovine neurophysin. A sample from each protein fraction, $5 \mu \mathrm{g}$ was iodinated with ${ }^{131} \mathrm{I}$ (6) and incubated with antiserum prepared against bovine neurophysin I, 1:5,000. Greater than $90 \%$ of each fraction was bound by this antiserum. When antiserum against human neurophysin was prepared and human neurophysin assays developed as described later, the binding of each human neurophysin by its specific antiserum could be $90-100 \%$ inhibited by the addition of excess bovine neurophysin (100 ng). PG I, II, III, and IV were further identified as neurophysins by their ability to bind an oxytocin analogue. The method was the same as described above for crude human neurophysin. The binding of (4- $\left[{ }^{14} \mathrm{C}\right]$ glycine) oxytocin to PG I, II, III, and IV at $\mathrm{pH}$ 5.8 was $73 \%, 72 \%, 72 \%$, and $76 \%$, respectively.

Antibodies to human neurophysins were produced as follows. Four white rabbits were injected with the CM I peak of human neurophysin eluted from Sephadex CM-50 (Fig. 2), and four rabbits were injected with the CM II peak. Each rabbit was injected with $200-500 \mu \mathrm{g}$ of neurophysin in $1 \mathrm{ml} 0.05 \mathrm{M}$ phosphate buffer ( $\mathrm{pH}$ 7.4) with an equal volume of complete Freund's adjuvant. One toe pad on each foot was injected at each innoculation, and the remaining antigen was injected subcutaneously in several areas of the back. Rabbits were injected four times bimonthly and were then bled. Antibody titers were obtained in every rabbit, and those with the highest titer were further stimulated biweekly over the next 4 mo. When toe pads became unusable, heel pads and subcutaneous injections of the back were utilized. Rabbits were periodically bled from the central vein of the ear, and the antisera were separated and stored frozen at $-20^{\circ} \mathrm{C}$.

Human neurophysins were iodinated as previously described (6). Protein determinations were by the method of Lowry et al. (15). The radioimmunoassay procedure was as previously described using zirconyl phosphate gel to separate bound and free protein (6). Statistical analyses of the assays were by the methods of Rodbard, Rayford, Cooper, and Ross (17). Neurophysin-free plasma was prepared by extracting $100 \mathrm{ml}$ of normal plasma with $6.5 \mathrm{~g}$ of uncoated charcoal. This removes $99 \%$ of a labeled trace of neurophysin. Cheng and Friesen (18) kindly provided some "human neurophysin I." 10 individual pituitaries were extracted in $0.1 \mathrm{~N} \mathrm{HCl}$ and diluted in $0.05 \mathrm{M}$ phosphate buffer ( $\mathrm{pH}$ 7.4) for protein determination and neurophysin assay. All of the Sephadex was from Pharmacia Fine Chemicals, Inc., Piscataway, N. J.

\section{RESULTS}

When the antisera of the rabbits immunized with specific peaks of human neurophysins were screened, two 


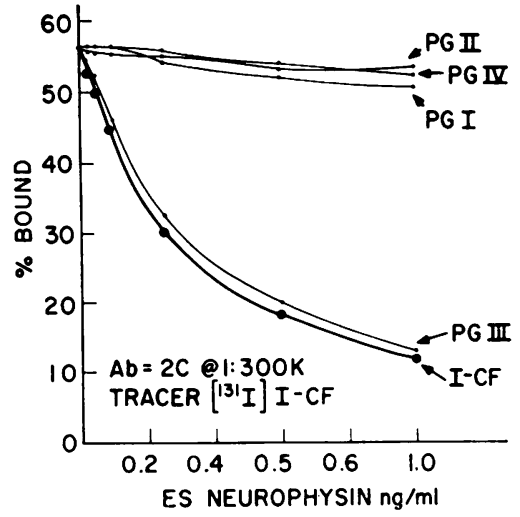

FIgURE 4 Standard curve for ESN. Human neurophysin I from Cheng and Friesen is used as the labeled and unlabeled neurophysin. Identity is seen with PG III. Lack of inhibition of binding is shown by PG I, II, and IV.

rabbits were found to produce antisera that detected specific antigenic sites on two of the human neurophysins. Rabbit $2 \mathrm{C}$ which was injected with peak $\mathrm{CM}$ II of CM-50 chromatography (Fig. 3) produced antiserum that recognized the human neurophysin from Cheng and Friesen (18). With this antiserum, the neurophysin from Cheng and Friesen showed complete identity with the PG III of preparative disk gel (Fig. 2 and 4). PG I, PG II, and PG IV from the preparative disk gel (Fig. 2) did not show identity in this assay as demonstrated by the lack of inhibition of binding (Fig. 4). For reasons described below, this assay is referred to as estrogen-stimulated neurophysin (ESN). ${ }^{1}$ (Earlier preparations of PG III showed greater crossreaction in this assay, and therefore, we continue to use the Cheng-Friesen neurophysin as the ESN assay standard.) Rabbit 1D which was injected with peak CM I of CM-50 chromatography (Fig. 3) produced antibody that recognized PG I, PG II, and PG IV of the preparative disk gel (Fig. 2) but not PG III nor the neurophysin from Cheng and Friesen (Fig. 5). This assay, as explained later, is referred to as nicotinestimulated neurophysin (NSN).

For each assay, antiserum is diluted to give $50-60 \%$ binding of the radiolabeled trace. Assay incubations are made up in barbitul buffer, $0.1 \mathrm{M} \mathrm{pH} \mathrm{8.6,} \mathrm{with}$ $0.5 \%$ human serum albumin. $50 \mu 1$ neurophysin-free human plasma is added to each tube in the standard curve, and $50 \mu 1$ plasma is assayed in the experimental samples. The final volume is $0.5 \mathrm{ml}$. All samples are run in duplicate. The radioactive neurophysin is added 2 days after the other reagents, and the incubation is continued another 5 days. Assay tubes with plasma

${ }^{1}$ Abbreviations used in this paper: DES, diethylstilbestrol; ESN, estrogen-stimulated neurophysin; NSN, nicotine-stimulated neurophysin. but without antibody are run for each sample and consistently have less than $6 \%$ nonspecific binding. The first point on the standard curve, $0.025 \mathrm{ng}$, can always be distinguished from zero. The minimum detectable level of neurophysin in $50 \mu \mathrm{l}$ plasma is $0.5 \mathrm{ng} / \mathrm{ml}$.

The intra-assay reproducibility of each assay was investigated by comparing duplicates in several assays. Samples for analysis were selected at random from 10 assays. 10 samples from each assay were selected for each of the groups $0-1 \mathrm{ng} / \mathrm{ml}, 1-5 \mathrm{ng} / \mathrm{ml}, 5-10 \mathrm{ng} / \mathrm{ml}$, and $>10 \mathrm{ng} / \mathrm{ml}$ based on the mean of the duplicates (Table I) (some assays did not have 10 samples for each group). Individual neurophysin values were then calculated for each of the paired duplicates of each sample. The SD of the difference of duplicates at various neurophysin levels was calculated by the method of Rodbard et al. (17). Results in Table II show that the most reproducible part of both assays is from 5-10 $\mathrm{ng} / \mathrm{ml}, 6-8 \% \mathrm{SD}$, while greater variation is present at low concentrations of both neurophysins. The between assay variation was determined by repeated assays of a medium level pool of "normal plasma" obtained from random blood samples of hospitalized patients, from an elevated level pool of "uremic plasma" obtained from random samples of hospitalized patients with elevated creatinine, and from a low level pool of "neurophysin-free plasma." The neurophysin-free plasma had no measurable neurophysin in any assay, and statistical calculations were not done for this sample. For the ESN assay, there is slightly greater between assay than within assay variation, but with the NSN assay the between assay variation was much greater than the within assay variation. At this time, the NSN assay is most useful for physiologic studies where

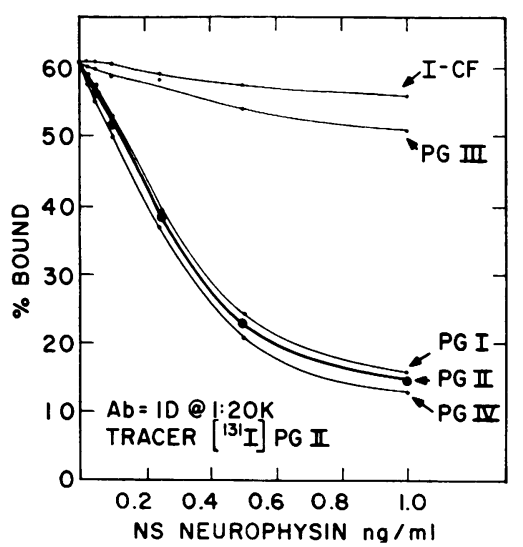

FI URE 5 Standard curve for NSN. Neurophysin band PG II from preparative disk gel electrophoresis is used as the labeled and unlabeled neurophysin. Identity of PG I, II, and IV is shown. Lack of inhibition of binding by PG III and HNp I-CF is seen. 
TABLE II

Reproducibility of Neurophysin Assays

\begin{tabular}{lrrrrr}
\hline \multicolumn{1}{c}{ Group } & Samples & Assays & Mean & SD & SD \\
\hline A. ESN & & & $n g / m l$ & $n g / m l$ & $\%$ \\
Within assay & & & & & \\
$0-1 \mathrm{ng}^{*}$ & 100 & 10 & 0.5 & 0.07 & 14 \\
1-5 ng & 84 & 10 & 2.9 & 0.33 & 12 \\
$5-10 \mathrm{ng}$ & 36 & 9 & 6.6 & 0.50 & 8 \\
>10 ng & 24 & 6 & 13.6 & 1.54 & 11 \\
Between assay & & & & & \\
Low pool & 1 & 12 & $<0.5$ & - & - \\
Medium pool & 1 & 15 & 3.2 & 0.52 & 16 \\
Elevated pool & 1 & 15 & 7.1 & 0.83 & 12 \\
B. NSN & & & & & \\
Within assay & & & & & \\
0-1 ng* & 100 & 10 & 0.5 & 0.09 & 18 \\
1-5 ng & 98 & 10 & 2.5 & 0.35 & 16 \\
5-10 mg & 14 & 4 & 6.9 & 0.38 & 6 \\
>10 ng & 4 & 2 & 14.3 & 2.26 & 16 \\
Between assay & & & & & \\
Low pool & 1 & 12 & $<0.5$ & - & - \\
Medium pool & 1 & 15 & 0.9 & 0.43 & 47 \\
Elevated pool & 1 & 15 & 2.2 & 0.7 & 31 \\
\hline
\end{tabular}

* Samples with unmeasurable neurophysin, less than 0.5 $\mathrm{ng} / \mathrm{ml}$, were assigned the value $0.4 \mathrm{ng} / \mathrm{ml}$.

serial samples from the same subject can be measured in the same assay.

For the ESN neurophysin assay (Fig. 4), the mean neurophysin of 320 samples from 32 normal ambulatory young women was $1.1 \mathrm{ng} / \mathrm{ml} \pm 0.7 \mathrm{SD}$, and in 107 samples from 54 normal men was $1.0 \pm 0.7 \mathrm{SD}$. Women on oral contraceptives have a significantly elevated neurophysin by this assay. The mean of 136 plasma samples from 22 women on oral contraceptives was $7.0 \mathrm{ng} / \mathrm{ml} \pm 5.2 \mathrm{SD}$. This elevation is highly significant $(P<0.001)$. Fig. 6 demonstrates the elevation of this neurophysin in five men given $10 \mathrm{mg}$ diethylstilbestrol (DES) for 2 days. This and other data have demonstrated that it is the estrogen of oral contraceptives that causes the neurophysin elevation (19), and we refer to this neurophysin as ESN. No significant difference is measureable using the other NSN neurophysin assay in women on oral contraceptives $(2.0 \pm 2.0$ $\mathrm{SD}$ ) nor in the DES-treated males (Fig. 6).

Normal plasma samples assayed with the NSN neurophysin assay based on PG II from the preparative disk gel (Fig. 5) had a mean neurophysin of $0.9 \mathrm{ng} / \mathrm{ml}$ $\pm 0.3 \mathrm{SD}$ in women and $0.6 \mathrm{ng} / \mathrm{ml} \pm 0.3 \mathrm{SD}$ in men. This neurophysin was not stimulated by estrogen administration but was stimulated by nicotine. Smoking two cigarettes in 15 min produced a rise of this neurophysin in 9 of 13 normal subjects (Fig. 7). All subjects were regular smokers (1-20 cigarettes per day) and had abstained from smoking for $12 \mathrm{~h}$ preceding the test. In women, this response was independent of whether the women were or were not taking oral contraceptives. No change was observed in ESN after smoking (Fig. 7). The four subjects who had no elevation of NSN after smoking were retested and again found to be unresponsive while four subjects who were responsive were retested, and again responded. We call this neurophysin NSN.

10 human pituitaries were carefully cleaned of all fibrous tissue and individually extracted in $0.1 \mathrm{~N} \mathrm{HCl}$. Protein concentration was determined, and each sample was diluted in buffer and assayed for ESN and NSN at several dilutions (Table III). In every gland there was more NSN than ESN with a mean NSN/ESN ratio of 3.3. The neurophysin content of the acid extract ranged for $14-79 \%$ of the total protein in the extract. The sum of ESN plus NSN may overestimate

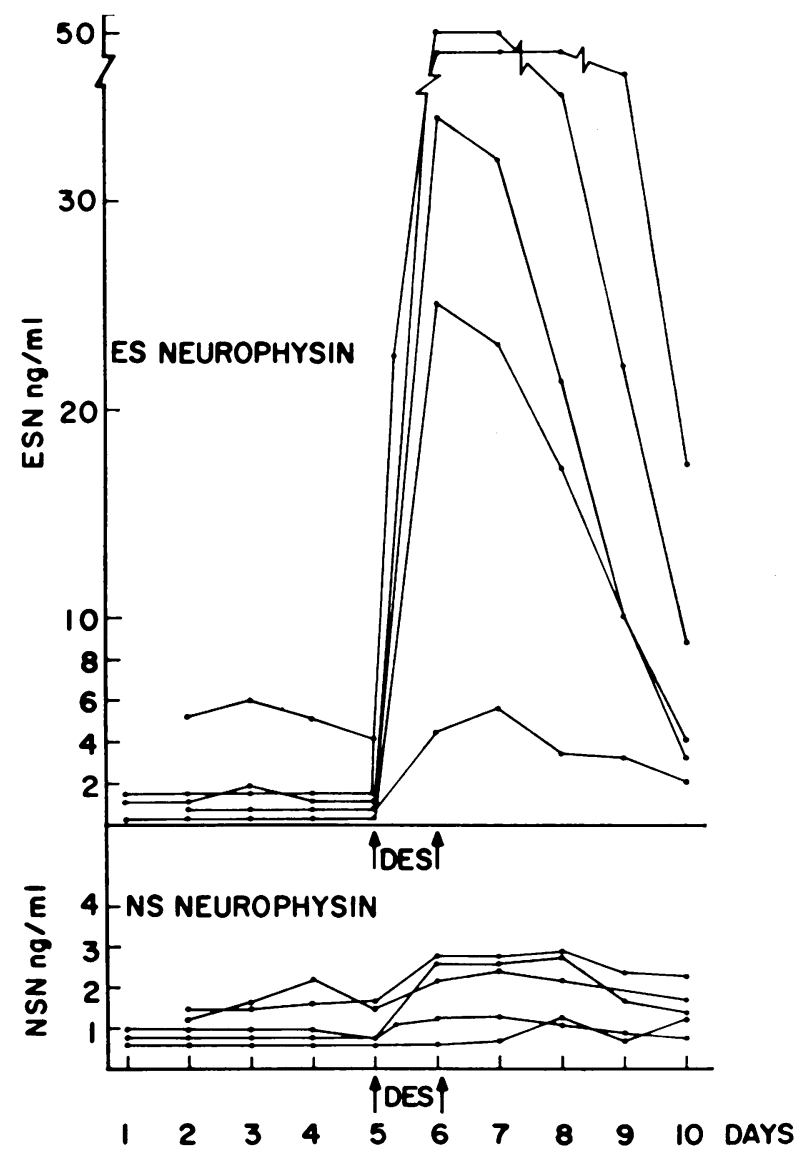

Figure 6 Comparison of changes in plasma ESN, top, and NSN bottom, in five normal male subjects given 5 mg DES on days 5 and 6. 


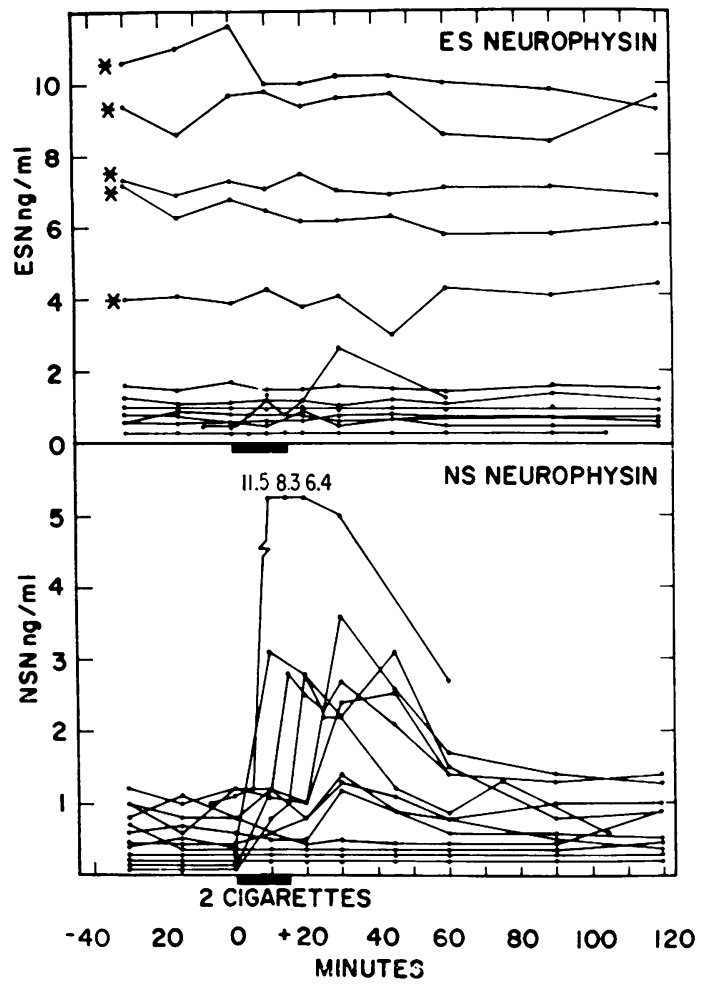

Figure 7 Comparison of changes in plasma ESN (top) and NSN (bottom) in 13 normal subjects who smoked two cigarettes from 0 to $15 \mathrm{~min}$. The $(*)$ indicates women on oral contraceptives containing estrogen. In one subject there was a rise in plasma ESN to $2.6 \mathrm{ng} / \mathrm{ml}$ at $30 \mathrm{~min}$. This was the subject whose NSN rose to $11.5 \mathrm{ng} / \mathrm{ml}$.

the total neurophysin because of slight crossreaction between the assays, but even if only one assay (NSN) is considered, neurophysin constitutes nearly $50 \%$ of the protein in the acid extract. As approximately $10 \%$ of the dry weight of human pituitaries is extracted in acid, Table I, approximately $5 \%$ of the gland by weight is neurophysin.

\section{DISCUSSION}

In a previous report of human neurophysins, Cheng and Friesen described the extraction of neurophysin from acetone-dried whole human pituitary powder which had been pre-extracted for gonadotropins (18). It is understandable that neurophysin is present in high concentration in extracts of whole pituitaries because of the high percentage of the weight of the posterior pituitary that is neurophysin, $5 \%$. The extraction procedure used here is a standard method (14), and $10 \%$ of the pituitary extract was isolated as crude neurophysin. As radioimmunoassay indicated that more than $50 \%$ of the acid extract was neurophysin, this method is only $20 \%$ efficient. Two main neurophysins were isolated by Cheng and Friesen from the extracts of whole human pituitaries (18). The radioimmunoassays which were developed showed considerable crossreactivity between these two neurophysins (20) similar to what we found using heterologous antisera (21).

Watkins, in a preliminary communication, compared neurophysins from the human posterior pituitary with neurophysins from other species (22). A partially purified sample of human neurophysin contained four distinct neurophysin bands by starch gel electrophoresis. Our results demonstrate that the number of bands of human neurophysin one obtains may depend upon the method of isolation. Previous investigators have shown that the $\mathrm{pH}$ of the initial extraction may influence the number of neurophysins obtained at later steps in the isolation (23) because of enzymatic degradation. All the extractions reported here started with $0.1 \mathrm{~N} \mathrm{HCl}$ which is thought to give the fewest number of neurophysin bands (23). At this $\mathrm{pH}$, enzymatic degradation of neurophysin during subsequent steps is inhibited. In spite of this, we obtained a predominance of two neurophysins by chromatographic separation (Fig. 2), but we obtained four bands of human neurophysin by preparative disk gel electrophoresis separation (Fig. 2). The two main bands isolated by column chromatography, Sephadex CM-50, are identical with the middle two of the four bands that were isolated by preparative disk gel (Fig. 2). The neurophysin from Cheng and Friesen (human neurophysin I) has a mobility identical with the second neurophysin off Sephadex CM-50 or the third band eluted from preparative disk gel (Fig. 2). The immunologic

TABLE III

Neurophysin Content of Individual Human Posterior Pituitaries

\begin{tabular}{llccc}
\hline & $\begin{array}{c}\text { Total } \\
\text { protein } \\
\text { extracted }\end{array}$ & $\begin{array}{c}\text { ESN/mg } \\
\text { protein }\end{array}$ & $\begin{array}{c}\text { NSN/mg } \\
\text { protein }\end{array}$ & $\begin{array}{c}\text { Neurophysin } \\
\text { ESN + NSN }\end{array}$ \\
\hline mg & $\mu g$ & $\mu g$ & $\%$ \\
& 0.19 & 78 & 388 & 47 \\
& 0.28 & 104 & 417 & 52 \\
& 0.43 & 202 & 584 & 79 \\
& 0.60 & 185 & 293 & 48 \\
& 0.67 & 91 & 540 & 63 \\
& 0.71 & 125 & 603 & 73 \\
& 0.96 & 43 & 353 & 41 \\
Mean & 0.85 & 237 & 357 & 59 \\
& 1.0 & 122 & 106 & 14 \\
& 1.4 & 31 & 397 & 55 \\
& 0.62 & 67 & 150 & 53 \\
\hline
\end{tabular}


identity of the first, second, and fourth bands of neurophysin in the preparative disk gel are unexplained.

More than two neurophysins have been described in the cow (11), rat (12), and in preliminary work in the human (22). However, it is of note that although radioimmunoassays of neurophysins have been reported in several animal species, the assays have not distinguished between various neurophysins of that species. The cow is the only animal where specific immunoassays for two neurophysins from the same species have been described (6). In the cow, independent secretion of two neurophysins was demonstrated (7). Other investigators have described a third neurophysin in bovine pituitary (11). In some bovine neurophysin preparations that we isolated subsequent to our previous reports (6), we also have detected a third band of bovine neurophysin. This band in our preparation was discussed in a report of a third neurophysin in porcine pituitaries (11). We have since isolated this third bovine neurophysin by preparative disk gel electrophoresis and found that it reacts with identity with our previously described bovine neurophysin II assay (unpublished observation).

We have now demonstrated that specific and independent immunoassays of two neurophysins can be accomplished in the human. The distinct neurophysins are PG II and PG III, as obtained by preparative disk gel electrophoresis. The protein which has been described as human neurophysin I by Cheng and Friesen is immunologically identical with PG III (Fig. 4). One might anticipate that their human neurophysin II is similar to our PG IV, which we have determined to be immunologically identical with PG II and PG I.

Thus, while numerous neurophysins may be described by a variety of isolation techniques, there are no data from any species to indicate that there are more than two antigenically distinct neurophysins in a given species. Indeed, our data described here in the human and the data in the cow would indicate that even multiple bands of neurophysin that are isolated by electrophoresis may be identified as only two different neurophysins by their antigenicity. Furthermore, these antigenic differences are physiologically significant. We have shown not only that both types of neurophysin are secreted into plasma, but that they are secreted independently and are stimulated by different pharmacologic agents.

It now seems likely that the assays of neurophysin in the human that used either heterologous $(4,9,24)$ or less specific homologous (17) radioimmunoassays have measured a summation of both neurophysins or have measured predominantly ESN. This accounts for the ease of measuring neurophysin in women who are pregnant $(9,24)$ and in women who are taking oral contraceptives (19). The human neurophysin studies described by Legros and Franchimont (9) specifically denied an elevation of neurophysin after cigarette smoking, indicating that this heterologous assay did not detect NSN.

The ability to measure two distinct neurophysins in the human complements our previous work in the cow and supports the contention that there may be a specific oxytocin neurophysin and a separate vasopres$\sin$ neurophysin. Estrogen is a stimulus for one neurophysin, and this is a plausible explanation for the elevation of neurophysin in pregnancy (24). Estrogen is not known to be a stimulus for oxytocin secretion. However, recent data on human pregnancy by Kumaresan, Anandarangam, and Vasicka have indicated that oxytocin is elevated in pregnancy plasma by the end of the first trimester and remains elevated throughout gestation (25). If oxytocin is elevated this long, it would correlate well with our previous reports of neurophysin levels in human pregnancy (24). Nicotine is considered a specific stimulus for vasopressin (26). In a preliminary report (27) that was recently submitted for publication, we have demonstrated in human volunteers a correlation between neurophysin release and vasopressin release after smoking. Therefore, we propose that the two human neurophysin assays described here might prove to be a specific oxytocin neurophysin assay, ESN, and a specific vasopressin neurophysin assay, NSN. Assay of these two neurophysins provides a useful new measure of human neurohypophyseal function.

\section{ACKNOWLEDGMENTS}

Human pituitaries were kindly provided by the National Pituitary Agency of the University of Maryland and by the National Institute of Arthritis, Metabolism, and Digestive Diseases. The technical expertise of Ms. Catherine Lewis and the secretarial skill of Ms. Barbara Brenneman and Ms. Karen Bodnar were of immeasurable assistance. Ms. Evelyn Schmidt and the nurses on the Clinical Research Unit performed the clinical studies with their usual perfection. Dr. James B. Field continues to provide his wise consultation. Oxytocin analogue $\left(4-\left[{ }^{15} \mathrm{C}\right]\right.$ glycine $)$-oxytocin was provided by Dr. J. McKelvey of the University of Connecticut, and Dr. Victor Hruby, University of Arizona.

This paper was supported by National Institute of Health Grant AM 16166 and Clinical Research Unit Grant FR 56, and Grant M74.32 from The Population Council, New York.

\section{REFERENCES}

1. Robinson, A. G., and A. G. Frantz. 1973. Radioimmunoassay of posterior pituitary peptides: a review. Metab. (Clin. Exp.). 22 : 1047-1057.

2. Fawcett, C. P., A. E. Powell, and H. Sachs. 1968. Biosynthesis and release of neurophysin. Endocrinology. 83: 1299-1310. 
3. Sachs, H., P. Fawcett, R. Portanova, and Y. Takabatake. 1969. Biosynthesis and release of vasopressin and neurophysin. Recent Prog. Horm. Res. 25: 447-491.

4. Legros, J. J., P. Franchimont, and J. C. Hendrick. 1969. Dosage radioimmunologique de la neurophysine dans le sérum des femmes normales et des femmes encientes. C. R. Seances Soc. Biol. Fil. 163: 2773-2777.

5. Cheng, K. W., and H. G. Friesen. 1970. Physiological factors regulating secretion of neurophysin. Metab. (Clin. Exp.). 19: 876-890.

6. Robinson, A. G., E. A. Zimmerman, E. G. Engleman, and A. G. Frantz. 1971. Radioimmunoassay of bovine neurophysin: specificity of neurophysin $I$ and neurophysin II. Metab. (Clin. Exp.). 20: 1138-1147.

7. Robinson, A. G., E. A. Zimmerman, and A. G. Frantz. 1971. Physiologic investigation of posterior pituitary binding proteins neurophysin I and neurophysin II. Metab. (Clin. Exp.). 20: 1148-1155.

8. McNeilly, A. S., J. J. Legros and M. L. Forsling. 1972. Release of oxytocin, vasopressin, and neurophysin in the goat. J. Endocrinol. 52: 209-210.

9. Legros, J. J., and P. Franchimont. 1972. Human neurophysin blood levels under normal, experimental, and pathological conditions. Clin. Endocrinol. 1: 99-113.

10. Burton, A. M., J. L. Forsling, and M. J. Martin. 1971. Release of neurophysin, oxytocin, and arginine vasopressin in the rat. J. Physiol. (Lond.). 217: 23-24.

11. Cheng, K. W., and H. G. Friesen. 1971. Isolation and characterization of a third component of porcine neurophysin. J. Biol. Chem. 246: 7656-7665.

12. Burford, G. D., C. W. Jones, and B. T. Pickering. 1971. Tentative identification of a vasopressin-neurophysin and an oxytocin-neurophysin in the rat. Biol. Chem. J. 124: 809-813.

13. Ginsburg, M., K. Jayasena, and P. J. Thomas. 1966. Subfractions from porcine neurophysin with different hormone binding properties. J. Physiol. (Lond.). 183: 45-46.

14. Hollenberg, M. D., and D. B. Hope. 1968. The isolation of the native hormone-binding proteins from bovine pituitary posterior lobes: crystallization of neu-
rophysin-I and -II as complexes with (8-arginine)vasopressin. Biochem. J. 106: 557-564.

15. Lowry, O. H., N. J. Rosebrough, A. L. Farr, and R. J. Randall. 1951. Protein measurement with the Folin phenol reagent. J. Biol. Chem. 193: 265-275.

16. Kapadia, G., and A. Chrambach. 1972. Recovery of protein in preparative polyacrylamide gel electrophoresis. Anal. Biochem. 48: 90-102.

17. Rodbard, D., P. L. Rayford, J. Cooper, and G. T. Ross. 1968. Statistical quality control of radioimmunoassays. J. Clin. Endocrinol. Metab. 28: 1412-1418.

18. Cheng, K. W., and H. G. Friesen. 1972. The isolation and characterization of human neurophysin. J. Clin. Endocrinol. Metab. 34: 165-176.

19. Robinson, A. G. 1974. Elevation of plasma neurophysin in women on oral contraceptives. J. Clin. Invest. 54: 209-212.

20. Cheng, K. W., and H. G. Friesen. 1973. Studies of human neurophysin by radioimmunoassay. J. Clin. Endocrinol. Metab. 36: 553-560.

21. Robinson, A. G., and E. A. Zimmerman. 1973. Cerebrospinal fluid and ependymal neurophysin. J. Clin. Invest. 52: 1260-1267.

22. Watkins, W. B. 1971. Neurophysins of the human pituitary gland. J. Endocrinol. 51: 595-596.

23. Dean, C. R., M. D. Hollenberg, and D. B. Hope. 1967. The relationship between neurophysin and the soluble portions of pituitary neurosecretory granules. Biochem. J. 104: 8C-10C.

24. Robinson, A. G., D. F. Archer, and L. F. Tolstoi. 1973. Neurophysin in women during oxytocin related events. J. Clin. Endocrinol. Metab. 37: 645-652.

25. Kumaresan, P., B. Anandarangam, and A. Vasicka. 1972. Studies of human oxytocin with radioimmunoassay. Excerpta Med. Int. Congr. Ser. no. 256: 516. (Abstr.)

26. Dingman, J. F., K. Benirshke, and G. W. Thorn. 1957. Studies of neurohypophyseal function in man. Am. J. Med. 23: 226-238.

27. Husain, M. K., A. G. Frantz, F. F. Ciarochi, and A. G. Robinson. 1973. Nicotine-stimulated release of neurophysin (NP) and vasopressin (VP) in humans. Clin. Res. 21: 494 . 